UDK $614.71,614.715,504.064$

\title{
EXPOSURE ASSESSMENT FOR POPULATION TO FINE PARTICLES IN THE INFLUENCE ZONES OF EMISSIONS FROM INDUSTRIAL STATIONARY EMISSION SOURCES
}

\author{
I.V. May, A.A. Kokoulina, S.Y. Zagorodnov, E.V. Popova \\ FBSI "Federal Scientific Center for Medical and Preventive \\ Health Risk Management Technologies" \\ 82, Monastyrskaya St., Perm, 614045, Russia
}

\begin{abstract}
In the case of the metallurgical, mining and engineering industries the instrumental studies results of disperse composition of the emissions are described, normalized fractions $\mathrm{PM}_{2.5}$ and $\mathrm{PM}_{10}$ are isolated. Values of the sedimentation coefficients for fine particles with different properties are clarified. It is shown that the use of data on dust dispersed composition and reasonable sedimentation coefficients improves the accuracy of calculations by $1.5-2.5$ times. The described approach can improve the accuracy of influence zones for industrial enterprises dust emissions and exposure assessment.
\end{abstract}

Key words: dust and gas emissions; fine particles; $\mathrm{PM}_{10}, \mathrm{PM}_{2.5}$, exposure assessment, dispersion, fractional composition, sedimentation coefficient.

The danger of fine particles for human health has been proved by various multi-year Russian and foreign studies $[6,9,13-15,17,22]$. It was determined that the size of particles as wells as their chemical conent and shape is an important factor in determining the health effects $[13,14,22]$. The studies show that fine particle fractions - sized less than 10 (PM10) and 2.5 micron (PM2.5) present the biggest health hazard because of their prolonged presence in the atmosphere, long-range transportation and ability to penetrate in the lower pulmonary passages, and reach the bronchi and alveole $[9,15,17]$.

Today consistent assessment of public exposure to fine particles in the Russian Federation is challenged by the lack of real data on particle size distribution of industrial emissions. Available information is not consistent with the technological processes and used materials [10]. The Decree of the RF Ministry of Natural Resources of December 31, 2010 №579 On Establishing Sources of Hazardous Emissions (Air Pollutants) Subject to State Registration and Regulation, and of the List of Hazardous Substances Subject to State Registration and Regulation that approves the regulation of dust emission with the account for particle size is not implemented well. For example, Rospotrebnadzor in Perm Region reports that as of 2013, none of the

(C) May I.V., Kokoulina A.A., Zagorodnov S.Y., Popova E.V., 2014

May Irina Vladislavovna - DBS, Professor, Deputy Director for Science (e-mail: may@fcrisk.ru, tel.: +7 (342) 237-25-47).

Kokoulina Anastasiia Aleksandrovna - research associate of Department of Sanitary and Hygienic Analysis and Monitoring Systemic Methods (e-mail: maks@fcrisk.ru, tel.: +7 (342) 237-18-04).

Zagorodnov Sergey Yurievich - research associate of Department of Sanitary and Hygienic Analysis and Monitoring Systemic Methods (e-mail: zagorodnov@fcrisk.ru, tel.: +7 (342) 237-18-04).

Popova Ekaterina Vladimirovna - GIS-engineer of Department of Sanitary and Hygienic Analysis and Monitoring Systemic Methods (e-mail: popova@fcrisk.ru, tel.: +7 (342) 237-18-04). 
Scientific and methodological approaches to risk analysis

enterprises in Prikamie included the data on the size content of dust emissions in the inventory list of emission and discharge sources and, accordingly, fine dust was not taken into account when developing the standards for the maximum permissible concentrations in the sanitary-protection areas.

Current situation prevents consistent hygienic assessment of possible effects of the atmospheric air chemicals in the area of close proximity to the solid particle industrial emission sources.

The purpose of the research was to develop methodical approaches to the assessment of health effects of fine dust in the areas of exposure to industrial stationary pollution sources based on a scientific analysis of the particle size distribution and component composition of dust-and-gas mixes.

To reach this objective, we took the following steps: determined the fraction composition of dust-gas emissions indicating the regulated $\mathrm{PM}_{2,5}$ and $\mathrm{PM}_{10}$ fractions; determined the mass emission of $\mathrm{PM}_{2,5}$ and $\mathrm{PM}_{10}$ particles $(\mathrm{g} / \mathrm{s}$, $\mathrm{t} / \mathrm{year})$; validated the correct sedimentation coefficients depending on the particle-size distribution of dust and emission factors; and, finally, assessed public exposure in the affected areas.

The objects of the research include machine-building, mining and iron-and-steel enterprises in Perm and Perm Region.

Materials and methods. Production processes at the industrial enterprises were studied based on the analysis of technical documentation followed by a field study of the industrial facilities to identify the sources of dust emission, analyze their technological characteristics and operation environment. On the sources of dust emission, we conducted a direct instrumental survey of the emissions. The selection was made with the use of a twin-cyclone separator in successive separation of the particles of various fractions and filters with respective pore sizes and characteristics that allow maintaining the particle size of emissions. The period of sample selection was determined by the intensity of dust release on the source and constituted 2-20 minutes; the sampling rate totaled $20 \mathrm{in}^{3} / \mathrm{min}$. Air sampling was conducting was conducted at the maximum proximity to the source of dust release. We probed up to 5 repeat samples on each source, created one averaged (proportionated) sample which served as the base for all the calculations.

Evaluation of the total volume of dust released per unit of time was conducted with the use of gravitational method. The particle content of dust emission was determined with the help of laser particle size analyzer Microtrac S3500 (with a size range from $20 \mathrm{~nm}$ to $2000 \mu \mathrm{m}$ ). The results of the particle size analysis are used to calculate the mass concentration of $\mathrm{PM}_{2,5}$ and $\mathrm{PM}_{10}$ particle fractions. 
Scientific and methodological approaches to risk analysis

The shape of the dust particles was determined with the use of a high resolution scanning electronic microscope (magnification range 5-300,000X; accelerating voltage $-0.3-30 \mathrm{KV}$ ) with a S3400N HITACHI X-ray fluorescent attachment (detection range - 10-5 mass\%, minimum analysis area $-100 \mu \mathrm{m}$ ) at the Center of Collective Use of Perm National Research Polytechnic University.

The quantitative evaluation of the particles of the regulated fractions was conducted by determining their maximum one-time $(\mathrm{g} / \mathrm{s})$ or gross $(\mathrm{t} / \mathrm{year})$ emission in accordance with the standard methods [6].

The proper coefficient of the dust sedimentation rate (F) was selected when preparing for the calculation of emission dispersion of fine particles from industrial sources as a ratio between the sedimentation rate of specific-size particles and critical wind velocity calculated in accordance with standardized methods. The sedimentation rate of globule particles was calculated based on the Stock's law formula where the rate of particle sedimentation depends on their diameter and density as well as the properties of the sedimentation medium. The shape of the particles determined with the help of an electronic microscope was taken into account in the Stock's law formula by adding an equivalent diameter defined via $\chi$ coefficient with a value of 1 through 2.9 [4].

The sedimentation rate of each dust fraction was calculated based on standardized methods used in Russia [7] and programming tools that implement pollutant dispersion algorithms in the air. The calculations were made in several points at the borders of sanitary protection zones of the enterprises and at grid points of the enterprise location within a radius of two kilometers (area of expected pollution).

When evaluating public exposure, we used the values of maximum one-time or daily average maximum permissible concentrations $\mathrm{MPC}_{\mathrm{mo}}$ and $\mathrm{MPC}_{\mathrm{cda}}$ which total respectively 0.16 and $0.035 \mathrm{mg} / \mathrm{m}^{3}$ for $\mathrm{PM}_{2,5}$; and 0.3 and $0.06 \mathrm{mg} / \mathrm{m}^{3}$ for $\mathrm{PM}_{10}{ }^{1}$ and are brought into accordance with the reference levels recommended by the World Health Organization [9, 21].

The level of exposure was mapped and analyzed on the basis of ArcGIS 9.3 mapping platform with the use of vector area maps that show the locations of stationary dust release sources, the borders of sanitary protection zones, residential buildings, social, cultural and recreational buildings as well as the number of residents.

\footnotetext{
${ }^{1}$ Hygienic Standard 2.1.6.2604-10 Addendum № 8 to Hygienic Standard 2.1.6.1338-03 Maximum Permissible Concentration (MPC) for air pollutants in the residential areas.
} 
In 2011-2013, we analyzed over 600 dust samples released by technical devices, machinery and other sources; we conducted over 200 exposure evaluations in the areas affected by industrial enterprises.

Results and discussion. When analyzing the technical processes, we determined the following:

- the sources of particulate emission at iron and steel enterprises include agglomerative production (sintering plant), iron smelting, iron to steel processing, blast-furnace processing (blast furnace, ore-blending plant, casting yard), open-hearth plants, converter steelmaking plants, and coke-chemical plants;

- the sources of higher dust emission in mining dry sections include ore overturning and finished products facilities, loading-and-unloading operations, rattling noise, bolting machines, disintegration sections, and assembly lines;

- the sources of dust emission at machine-building enterprises include casting shops (cupola furnaces, electric arc furnaces, induction furnaces, storage areas, batch and molding material processing sections, casting removal and dressing sections), press and rolling-mill shops (metal heating and processing processes), heat-treating shops (batch-heating furnace, shot-blasting chambers), galvanizing plants (prior operations, mainly, mechanical cleaning), machine workshops (mechanical processing of metal, lumber, fiberglass, black-chalk, etc.), metal welding and cutting sections

Other sources of dust emission include auxiliary process sections: furnace rooms, maintenance rooms, building workshops, etc.

See Table 1 for the fractional makeup of dust emissions at iron-and-steel enterprises.

\section{Characteristics of the particle size distribution of dust from technological operations at metallurgical enterprises}

\begin{tabular}{|c|c|c|c|c|}
\hline \multirow[b]{2}{*}{ Technical operation } & \multicolumn{3}{|c|}{ Particle weight fraction, $\%$} & \multirow{2}{*}{$\begin{array}{c}\text { Median particle } \\
\text { size, } \\
\mu \mathrm{m}\end{array}$} \\
\hline & $\begin{array}{c}\text { less than } \\
2,5 \mu \mathrm{m}\end{array}$ & $\begin{array}{c}\text { less than } \\
10 \mu \mathrm{m}\end{array}$ & $\begin{array}{c}\text { more than } \\
10 \mu \mathrm{m}\end{array}$ & \\
\hline Charing hole load & 5,40 & 24,77 & 74,59 & 40,00 \\
\hline Single-component burden load & 0,00 & 9,19 & 90,81 & 80,00 \\
\hline Smelter slag load & 44,46 & 55,52 & 42,58 & 4,00 \\
\hline Batch mixing & 11,40 & 31,14 & 68,16 & 30,00 \\
\hline Agglomeration & 2,93 & 8,43 & 90,59 & 200,00 \\
\hline Agglomerate handling & 5,24 & 15,41 & 82,33 & 20,00 \\
\hline Rehandling (local agglomerate) & 4,07 & 25,57 & 74,43 & 20,00 \\
\hline Hot-metal tapping & 78,53 & 84,34 & 15,66 & 1,00 \\
\hline Slag tapping & 17,56 & 53,91 & 46,12 & 8,50 \\
\hline Blow-off of iron in a converter & 1,22 & 10,79 & 89,21 & 8,50 \\
\hline Rolled raw stock at rolling mill 370 & 12,06 & 26,87 & 72,15 & 40,00 \\
\hline Rolled raw stock at rolling mill 550 & 0,00 & 8,58 & 91,42 & 90,00 \\
\hline
\end{tabular}


Scientific and methodological approaches to risk analysis

\begin{tabular}{|l|c|c|c|c|}
\hline Lime roasting & 6,06 & 40,98 & 62,67 & 10,00 \\
\hline Ferrovanadium smelting & 4,71 & 26,95 & 73,05 & 20,00 \\
\hline Spring media blasting & 35,51 & 47,91 & 52,09 & 10,00 \\
\hline Steel felling & 12,79 & 29,44 & 70,56 & 20,00 \\
\hline Hot pressing & 1,32 & 18,01 & 81,99 & 80,00 \\
\hline Drilling-out of rod stocks & 0,37 & 11,06 & 88,94 & 90,00 \\
\hline Sand peeling & 11,36 & 50,58 & 49,42 & 40,00 \\
\hline Steel-making in an electric furnace & 16,71 & 38,22 & 61,78 & 20,00 \\
\hline $\begin{array}{l}\text { Formation of mixes in a form-making } \\
\text { mixer }\end{array}$ & 1,65 & 13,67 & 86,33 & 20,00 \\
\hline
\end{tabular}

It was determined that for the dust produced at the metallurgical enterprise under study, the median particle size ranged from 1.00 ('smelter slag load' procedure) to $200.00 \mu \mathrm{m}$ ('agglomeration' procedure). The content of $\mathrm{PM}_{2,5}$ fractions ranged from 0 to $78 \%, \mathrm{PM}_{10}-$ from 8 to $84 \%$ depending on the technological operation and used raw materials.

See figure 1 for a sample bar chart that shows the particle size distribution of dust from flushing of slag. The sizes of the particles in the emissions of dry sections at mining enterprises were as follows: $0-21 \%$ - particles sized less than $2.5 \mu \mathrm{m} ; 0-49 \%$ - particles sized less than $10 \mu \mathrm{m} ; 51-$ $100 \%$ - particles sized more than $10 \mu \mathrm{m}$ (Table 2).

The median particle size of dust for various technological processes was measured in the range from 10.00 to $450.00 \mu \mathrm{m}$.

The fractional composition of the dust obtained in the course of studies at the machinebuilding enterprises is shown in Table 3. The median particle size of dust in the emissions of machine-building enterprises from various technological metal-working processes ranged from 80 to $300 \mu \mathrm{m}$.

Overall, based on the study of various technological operations, the emissions from stationary sources at machine-building enterprises contain from 0 to 13 volume percent of $\mathrm{PM}_{2,5}$ particles and from 0 to $40 \% \mathrm{PM}_{10}$ particles. The biggest share of fine particles is registered at the welding sections (up to $70 \%$ ).

Emissions at all the enterprises under study contained particles of various shapes: globular, angular, elongated, tabular, combined, etc (Figure 2). 


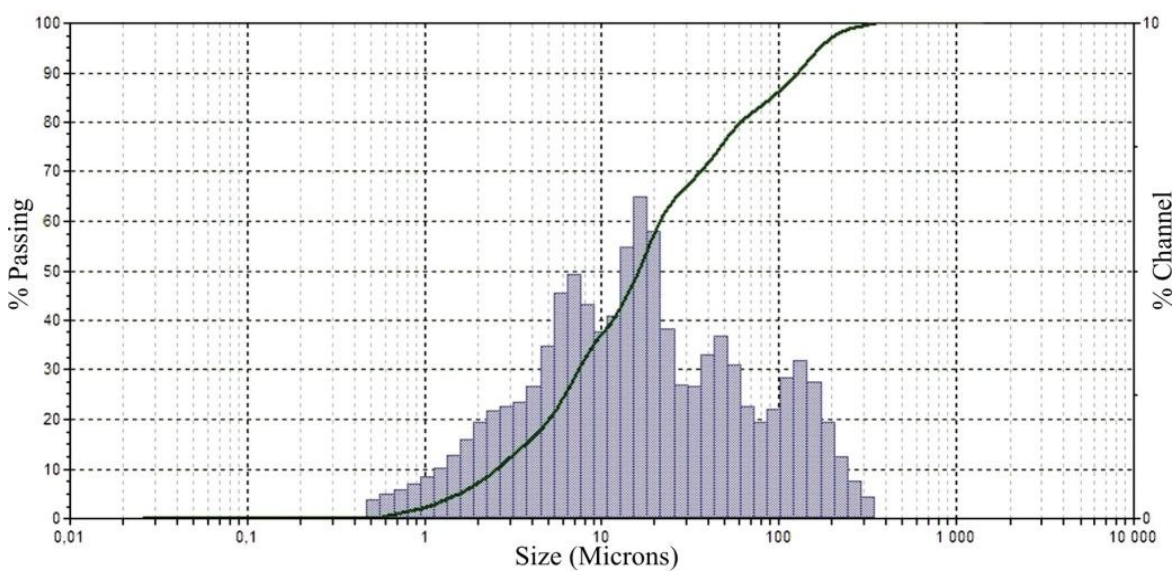

Figure 1. A bar chart of the particle size distribution of dust from flushing of slag

Table 2

\section{Characteristics of the particle size distribution of dust from some technological operations at dry sections of mining enterprises}

\begin{tabular}{|l|c|c|c|c|}
\hline \multirow{2}{*}{\multicolumn{1}{|c|}{ Technical operation }} & \multicolumn{3}{|c|}{ Particle weight fraction, \% } & Median \\
\cline { 2 - 4 } & $\begin{array}{c}\text { less than } \\
2,5 \mu \mathrm{m}\end{array}$ & $\begin{array}{c}\text { less than } \\
10 \mu \mathrm{m}\end{array}$ & $\begin{array}{c}\text { more than } \\
10 \mu \mathrm{m}\end{array}$ & $\begin{array}{c}\text { particle size, } \\
\mu \mathrm{m}\end{array}$ \\
\hline Overturning of ore at the belt conveyer & 0,90 & 2,40 & 97,60 & 60,00 \\
\hline Overturning of ore at the belt conveyer & 14,61 & 32,33 & 67,67 & 30,00 \\
\hline Overturning of ore at the belt conveyer & 13,64 & 48,65 & 51,35 & 10,00 \\
\hline Dyring of the material by flue gases & 0,00 & 0,00 & 100,00 & 60,00 \\
\hline Mixing of charge material in the conveyers & 6,19 & 48,41 & 51,59 & 10,00 \\
\hline Overutrning of the finished products & 2,32 & 14,90 & 85,10 & 80,00 \\
\hline Filtration of ore at the grater & 6,12 & 36,36 & 63,64 & 20,00 \\
\hline Filtration of ore at the grater & 14,25 & 43,76 & 56,24 & 20,00 \\
\hline $\begin{array}{l}\text { Drying of granulated material at the shake- } \\
\text { out drying-and-cooling station }\end{array}$ & 9,51 & 35,41 & 64,59 & 30,00 \\
\hline Filtration of agglomerate & 19,72 & 46,46 & 53,54 & 20,00 \\
\hline Stocking up of grain concentrate & 9,84 & 20,80 & 79,20 & 50,00 \\
\hline Stocking up of grain concentrate & 0,00 & 0,00 & 100,00 & 450,00 \\
\hline Stocking up of sylvinite & 20,90 & 40,41 & 59,59 & 20,00 \\
\hline
\end{tabular}

Table 3

Characteristics of the particle size distribution of dust from some technological operations at machine-building enterprises

\begin{tabular}{|c|c|c|c|c|}
\hline \multirow[b]{2}{*}{ Technical operation } & \multicolumn{3}{|c|}{ Particle weight fraction, $\%$} & \multirow{2}{*}{$\begin{array}{c}\text { Median particle } \\
\text { size, } \\
\mu \mathrm{m}\end{array}$} \\
\hline & $\begin{array}{l}\text { less than } \\
2,5 \mu \mathrm{m}\end{array}$ & $\begin{array}{l}\text { less than } \\
10 \mu \mathrm{m}\end{array}$ & $\begin{array}{c}\text { more than } \\
10 \mu \mathrm{m}\end{array}$ & \\
\hline 1 & 2 & 3 & 4 & 5 \\
\hline Steel part cutting using face grinders & 0,00 & 4,93 & 95,07 & 300,00 \\
\hline Steel part cutting using slitting machines & 7,07 & 32,97 & 67,02 & 200,00 \\
\hline Steel part cutting diamond grinding wheels & 0,37 & 15,29 & 84,71 & 100,00 \\
\hline Steel part cutting using chain grinders & 0,00 & 2,67 & 97,33 & 100,00 \\
\hline $\begin{array}{l}\text { Steel part cutting using horizontal boring } \\
\text { machines }\end{array}$ & 0,35 & 19,77 & 80,23 & 200,00 \\
\hline Steel part cutting using drill press & 6,7 & 13,45 & 86,55 & 100,00 \\
\hline Steel part cutting using lathe tool & 0,35 & 12,24 & 87,76 & 200,00 \\
\hline Steel part cutting using milling machines & 5,22 & 38,78 & 61,22 & 300,00 \\
\hline Steel part grinding using glass dust & 5,18 & 30,01 & 69,99 & 100,00 \\
\hline Steel part grinding in barreling machines & 0,55 & 16,84 & 83,16 & 200,00 \\
\hline
\end{tabular}


Scientific and methodological approaches to risk analysis

\begin{tabular}{|l|c|c|c|c|}
\hline Steel part grinding in blast cabinets & 0,00 & 0,00 & 100,00 & 100,00 \\
\hline $\begin{array}{l}\text { Processing of nonmetallic materials using } \\
\text { lathe machines }\end{array}$ & 0,32 & 8,78 & 91,22 & 100,00 \\
\hline $\begin{array}{l}\text { Semi-automatic steel welding in carbon } \\
\text { dioxide environment }\end{array}$ & 13,46 & 39,88 & 60,12 & 80,00 \\
\hline $\begin{array}{l}\text { Semi-automatic steel welding in argon } \\
\text { environment }\end{array}$ & 0,00 & 2,16 & 97,84 & 80,00 \\
\hline
\end{tabular}

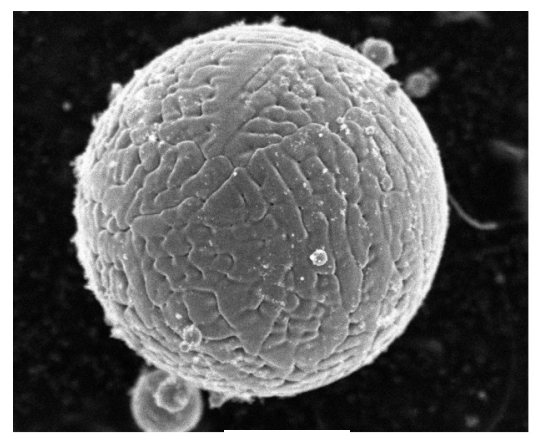

$\mathbf{a}$

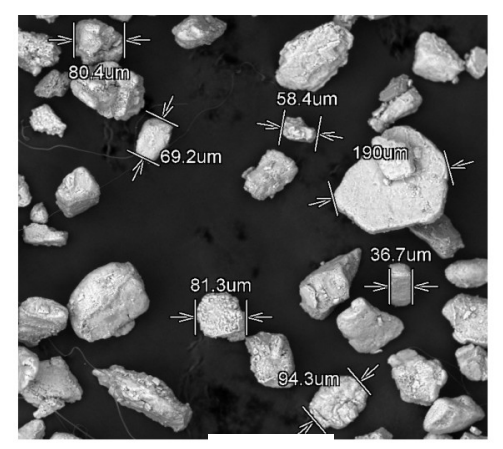

b

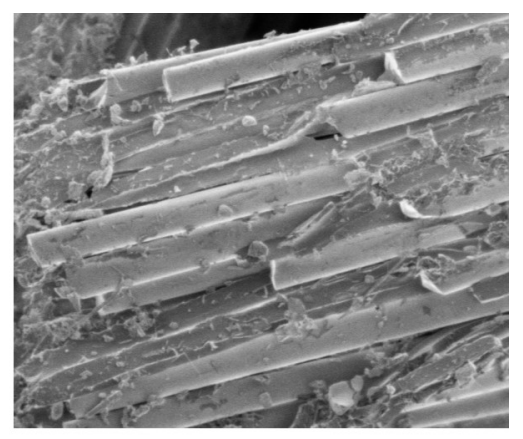

C

Figure 2. Examples of dust particle shapes identified via electronic microscopy (a - globular, b - combined, c - elongated)

In most cases, dusts included a wide range of nano-sized particles (Figure 3).

The sedimentation coefficients calculated for separate types of dust fell in the range from 1 to 2.0. In a number of cases, the newly established coefficients were by 2.0-2.5 times different from the ones used before; for the latter, the fractional composition was not determined which had a great effect on the calculation of the atmospheric diffusion and, accordingly, on the values of the ground-level doping concentrations.

Calculations of the dispersion of dust from the sources under study at the machinebuilding enterprises with the account for the obtained data on the fractional composition suggests that in unfavorable environmental conditions, the maximum ground level $\mathrm{PM}_{10}$ concentration at the borders of the sanitary protection zone totaled 1,5 $\mathrm{MPC}_{\text {maximum one-time. }}$

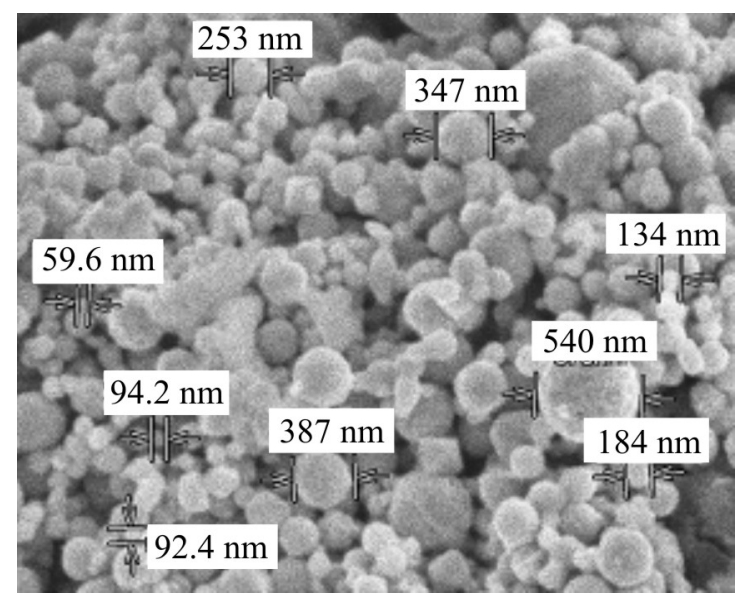

Figure 3. Electronic photo of dust produced when rolling raw stock at rolling mill 550 (magn. $\times 10000)$ 


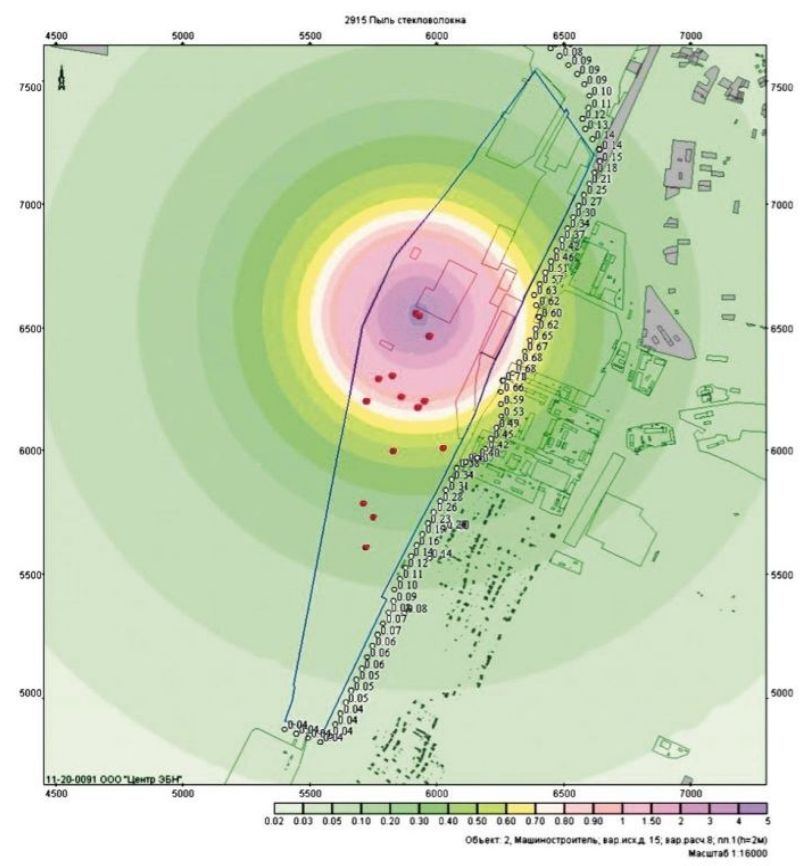

a

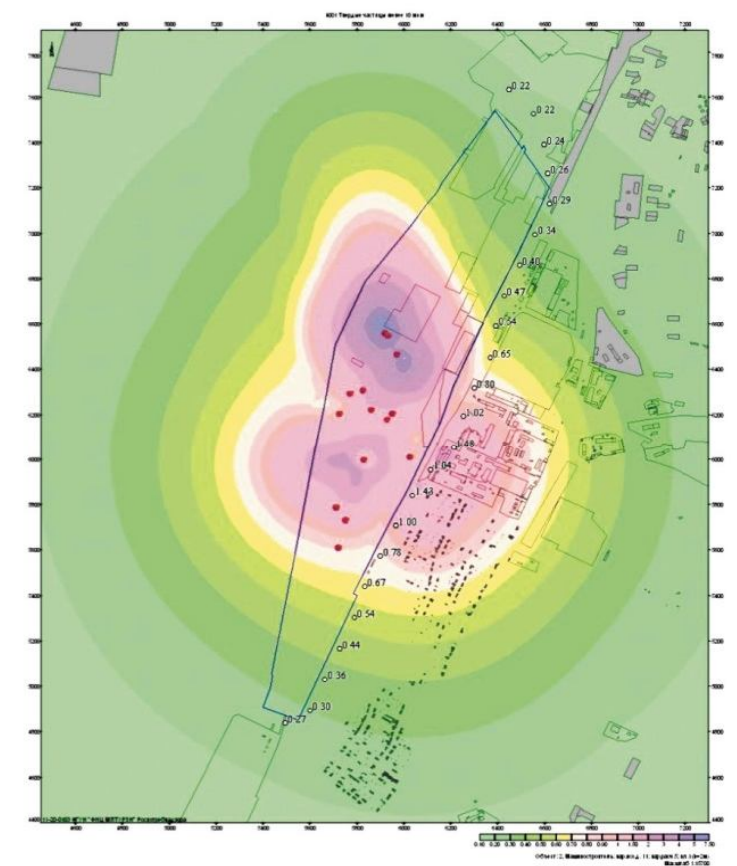

b

Figure 4. Isolines of dust dispersion in unfavorable environmental conditions (no-wind; $t 25{ }^{\circ} \mathrm{C}$ ) ( $a$ - with no account for disparity; $b$ - with the account for disparity)

When integrating the calculation data for dispersion and electronic layers characterizing the population, it was determined that 1286 people reside in an area with poor hygienic standards just outside of the sanitary protection zone. Based on the data, we reviewed the results of earlier sanitary-hygienic assessments which had revealed no hazardous air pollution levels (Figure 4). The obtained data confirmed the hypothesis that it is necessary to take into account the particle distribution of dust when validating the sanitary-protection zone projects and maximum permissible concentration standards since in the areas of dust exposure, the distance of 50, 100 and 200 meters often might be considerable from the legal and hygienic points of view [2].

Conclusions. The majority of dust-and-gas emissions at the metallurgical, machinebuilding and mining enterprises under study contained small dust fractions - up to $80 \%$ PM10 and up to $40 \%$ PM2,5. The particle distribution of emitted dust is heterogeneous and depends on the specific technological process and used devices, tools, and raw materials.

Emissions from many technological processes contained nanoparticles. This fact requires special-target studies to analyze their impact on the employees and the population at large.

The calculation of an adequate sedimentation coefficient for the dust particles of various fractions and different characteristics allows for the increase of their ground-level concentrations and, respectively, of public exposure. 


\section{Scientific and methodological approaches to risk analysis}

Reporting on the fractional composition of dusts significantly increases the accuracy of the borders of exposure areas around the sources of emission as well as the accuracy of public exposure to hazardous fractions of solid emissions.

Introduction of the assessment of fractional composition of dusts into the validation of standards for maximum permissible concentrations and sanitary-protection zone projects should be considered as a tool to improve public sanitary and epidemiological well-being.

\section{References}

1. Azarov V.N. Kompleksnaya otsenka pylevoy obstanovki i razrabotka mer po snizheniyu zapylennosti vozdushnoy sredy promyshlennykh predpriyatiy: avtoreferat dissertatsii na soiskanie uchenoy stepeni doktora tekhnicheskikh nauk [Comprehensive assessment of dust conditions and development of measures to reduce dust content of industrial enterprises' air environment]. Rostov-na-Donu, 2004. 46 p.

2. Zaytseva N.V., May I.V., Maks A.A., Zagorodnov S.Yu. Analiz dispersnogo i komponentnogo sostava pyli dlya otsenki ekspozitsii naseleniya $\mathrm{v}$ zonakh vliyaniya vybrosov promyshlennykh statsionarnykh istochnikov [Analysis of the particulate and fractional composition of dust for the assessment of population exposure in areas of influence of emissions from industrial stationary sources]. Gigiena i sanitariya, 2013, no. 5, pp. 19-23.

3. Namazbaeva Z.I., Mukasheva M.A., Gulaeva O.V., Salimbaeva B.M., Dyusembaeva N.K., Adil'bekova A.A. i dr. Vozdeystvie pyli na narushenie reproduktivnoy funktsii organizma [Dust influence on organism reproductive disorders]. Gigiena i sanitariya, 2005, no. 5, p. 72.

4. Kouzov P.A. Osnovy analiza dispersnogo sostava promyshlennykh pyley i izmel'chennykh materialov [Fundamentals of the particulate composition of industrial dusts and particulate materials]. 3-e izd. pererab. Leningrad: Khimiya, 1987. 264 p.

5. May I.V., Maks A.A., Zagorodnov S.Yu., Chigvintsev V.M. Metodicheskie podkhody $\mathrm{k}$ uchetu skorosti osedaniya razlichnykh pylevykh fraktsiy dlya zadach otsenki ekspozitsii naseleniya melkodispersnymi chastitsami [Methodical approaches to the consideration of sedimentation rate of different dust fractions for the tasks of assessment of population exposure to fine particles]. Izvestiya Samarskogo nauchnogo tsentra Rossiyskoy Akademii Nauk, 2012, vol. 14, no. 5 (3), pp. 971- 975.

6. Metodicheskoe posobie po raschetu, normirovaniyu i kontrolyu vybrosov zagryaznyayushchikh veshchestv $\mathrm{v}$ atmosfernyy vozdukh (dopolnennoe i pererabotannoe) [Guidelines on the calculation, regulation and control of emissions into the atmosphere (revised and supplemented) ]. St. Petersburg, 2012. 222 p.

7. OND-86 Metodika rascheta kontsentratsiy $\mathrm{v}$ atmosfernom vozdukhe vrednykh veshchestv, soderzhashchikhsya $\mathrm{v}$ vybrosakh predpriyatiy. Obshchesoyuznyy normativnyy document [OND-86 Methods of calculating the concentrations in the air of harmful substances contained in industrial emissions. - Union regulatory document]. GGO im. Voeykova. Leningrad, $1987.64 \mathrm{p}$.

8. Onishchenko G.G., Novikov S.M., Rakhmanin Yu.A., Avaliana S.L., Bushtueva K.A. Osnovy otsenki riska dlya zdorov'ya naseleniya pri vozdeystvii khimicheskikh veshchestv, zagryaznyayushchikh okruzhayushchuyu sredu [Fundamentals of assessing public health risk from exposure to chemicals polluting the environment]. Ed. by Rakhmanin Yu.A., Onishchenko G.G. Moscow: NII ECh i GOS, 2002. 408 p.

9. R 2.1.10.1920-04. Rukovodstvo po otsenke riska dlya zdorov'ya naseleniya pri vozdeystvii khimicheskikh veshchestv, zagryaznyayushchikh okruzhayushchuyu sredu [P 
2.1.10.1920-04. Guidance for public health risk assessment from exposure to chemicals polluting the environment]. Moscow, 2004.

10. Skryabina L.Ya. Atlas promyshlennykh pyley. Part 1. Letuchaya zola teplovykh elektrostantsiy. 48 p. Part 2. Pyli predpriyatiy metallurgii, mashinostroeniya i stroitel'noy promyshlennosti $37 \mathrm{p}$. Part 3. Pyli predpriyatiy khimicheskoy i pishchevoy promyshlennosti [Atlas of industrial dusts. Part 1. Fly ash of thermal power plants. Part 2. Dusts of enterprises of metallurgy, engineering and construction industries. Part 3. Dusts of chemical and food industries]. Tsintikhimneftemash.: Moscow, 1980-1982.

11. Beccaceci S., Muhunthan D., Sarantaridis D., Tompkins J., Butterfield D., Quincey P., Brown R., Green D., Grieve A., Fuller G., Jones A. Airborne Particulate Concentrations and Numbers in the United Kingdom (phase 2). Annual Report - 2010. Report Date: $31 / 08 / 2011$.

12. Directive 2008/50/EC of the European Parliament and of the council of 21 May 2008 on ambient air quality and sleaner air for Europe. Official Journal of the European Union, 11.06.2008. $44 \mathrm{p}$.

13. Correia Andrew W. a; Pope C. Arden III b; Dockery, Douglas W. c; Wang, Yuna; Ezzati, Majidd; Dominici, Francescaa. Effect of Air Pollution Control on Life Expectancy in the United States: An Analysis of 545 U.S. Counties for the Period from 2000 to 2007. Epidemiology, January 2013, vol. 24, issue 1, pp. 23-31. DOI: 0.1097/EDE.0b013e3182770237. Air Pollution.

14. Kassomenos P.A., Dimitriou K., Paschalidou A.K. Human health damage caused by particulate matter PM (10) and ozone in urban environments: the case of Athens, Greece. Environ Monit Assess, 2013.

15. Jedrychowski W.A., Perera F.P., Spengler J.D., Mroz E., Stigter L., Flak E., Majewska R., Klimaszewska-Rembiasz M., Jacek R. // Intrauterine exposure to fine particulate matter as a risk factor for increased susceptibility to acute broncho-pulmonary infections in early childhood. Int J Hyg Environ Health, 2013, vol. 216 (4), pp. 395-401.

16. Kirk R. Smith. Global review of national ambient air quality standards for PM10 and SO2 (24 h). Air Qual Atmos Health, DOI: 10.1007/s11869-010-0131-2.2011.

17. Usanee U Vinitketkumnuen, Kittiwan K Kalayanamitra, Teera T Chewonarin, Richard R Kamens. Particulate matter, PM 10 \& PM 2.5 levels, and airborne mutagenicity in Chiang Mai, Thailand. Mutat Res, vol. 519 (1-2), pp. 121-131 (2002), PMID 12160897.

18. Joksic J.D., Jovasevic-Stojanovic M.V., Bartonova A., Radenkovic M.B, Yttri K.E., Matic-Besarabic S., Ignjatovic L.M. Physical and chemical characterization of the particulate matter suspended in aerosols from the urban area of Belgrade (Article). Journal of the serbian chemical society, 2009, vol. 74 br. 11, pp. 1319-1333.

19. Richard D. Cadle. Particle size: theory and industrial applications. Reinhold Pub. Corp., 1965. 390 p.

20. Joksic J.D., Radenkovic M.B., Cvetkovic A., Matic-Besarabic S., JovasevicStojanovic M.V., Bartonova A., Yttri K.E. Variations of PM10 Mass Concentrations and Correlations with Other Pollutants in Belgrade Urban Area (Article). Chemical industry \& chemical engineering quarterly, 2010, vol. 16 br. 3, pp. 251-258.

21. WHO guidelines for indoor air quality: selected pollutants. The WHO European Centre for Environment and Health, Bonn Office, WHO Regional Office for Europe coordinated the development of these WHO guidelines.

22. Wilson R. and Spengler J. Particles in Our Air: Concentrations and Health Effects. Cambridge, MA: Distributed by Harvard University Press, 1996. 